\title{
DEVELOPMENT OF EQUESTRIAN SPORTS AT STATE STUD FARMS IN VARMIIA AND MASURIA BETWEEN 1947 AND 1975
}

\author{
Zbigniew Wójcik, ${ }^{1, A, B, D}$ Renata Urban², A, B, D, E \\ 1 University of Warmia and Mazury in Olsztyn, Poland \\ ${ }^{2}$ University of Szczecin, Faculty of Physical Culture and Health Promotion, Szczecin, Poland \\ A Study Design; ${ }^{\mathrm{B}}$ Data Collection; ${ }^{\mathrm{D}}$ Manuscript Preparation; E Funds Collection \\ Address for corpespondence: \\ Renata Urban \\ University of Szczecin, Faculty of Physical Culture and Health Promotion \\ Al. Piastów 40b, building 6, 71-065 Szczecin, Poland \\ E-mail: renata.urban@usz.edu.pl
}

\begin{abstract}
Ahstract The regaining by the Polish People's Republic of territories that prior to the outbreak of World War 2 had remained under the rule of East Prussia set the stage for re-development of equestrianism in and reintroduction of horse breeding to a region that was now Polish Varmia and Masuria. This was a two-stage process whose success depended largely on the perseverance and commitment of one man, Mr. Adam Sosnowski, administrator at the State Horse Breeding Farms. The process was initiated in 1947 when a state stallion station in Ketrzyn and three studs named Garbno, Liski, and Rzeczna were started. Another eight were soon set up through the joint effort and collaboration of managements of local state farming cooperatives, or PGRs, mostly on the grounds of former Prussian horse breeding sites with appropriate technical infrastructure and solidly established stock breeding traditions. Over the years to come, equine breeding farms in Varmia and Masuria underwent numerous reforms and organizational changes, structurally always remaining part of the Polish Ministry of Agriculture. They provided a good foundation for propagating recreational horse riding among members of the general public and, most importantly, helped equestrian sports to return to and develop in the area.
\end{abstract}

Key Words equestrian sports, breeding, studs, horses, Varmia and Masuria

\section{Introduction}

For hundreds of years horse breeding and horse riding remained tightly intertwined with the history of warfare and human conflict. It is therefore understandable that for a relatively long period of time people perceived the ability to breed and ride the horse as an advantage critical to their own survival. These sentiments were no different among inhabitants of Varmia and Masuria (Donhoff, 1988; Kamzolov, 2002), where the leader in equine breeding was the Royal Stud in Trakehnen (Grodzicki, Pacyński, 1966). For over 200 years since its establishment in 1732, the stud enjoyed wide prestige, a fact well illustrated by a steady demand for the fine Trakenher horse it produced and an unfaltering popularity of an on-site museum exhibiting paintings and pottery with images of the most successful mounts. 
Professional training of young stallions in East Prussia started in 1823. The first official horse race was held a dozen or so years later, in Konigsberg (Królewiec), where by 1875 the Royal Horse Racing Federation had already been in full operation (Knoblauch, 1939, p. 16). After the post-WW2 border shift, Polish breeders who had arrived in the region relied on the Prussian experience, organizing in what was then officially called 'the Regained Territories' the first Polish studs and stallion stations (Grodzicki, Pacyński, 1966). The stimulus to resume horse breeding came primarily from the fact that a number of Trakenhers survived the war but were scattered across the country, and that the necessary infrastructure remained at many breeding sites relatively intact (Josse, 1959; Pacyński, 1960; Jegielski, 2002; Jastrzębska, 2002; Kamzolov, 2002; Wójcik, Skrzypczak, 2014; and others).

The emergence of equestrian sports in this area dates back to the middle 1850s (Wójcik, 2010). It was around that time that a clear relationship between stock breeding and equestrianism was observed, the latter positively correlating with cavalry training. This is one of the reasons why Prussian cavalry officers were obliged to take part in flat and hunt races (Pruchniewicz, 2003, p. 291). In the years to come, the military use of the horse was to become an invaluable contributor to the propagation of horse riding among members of the general public (Pruski, Grabowski, Schuch, 1963, p. 607). The Prussian military initiated a number of ventures that aimed at improving the manner in which the horse could be used. Manèges were built to allow introduction of elements of the Haute Ecole to everyday training in order to develop obedience and other desirable qualities that a well-trained cavalry horse should demonstrate in the battlefield. These efforts to harmoniously cultivate the inborn predispositions of the horse lay at the foundation of the gradually emerging dressage. Literature on the subject contains references to a dressage contest held in Bratislava as early as in 1873 (Wójcik, 2010, p. 19). Soon the principles of the new equine discipline spread to other European countries.

Yet it was not dressage but jumping that attracted decidedly more enthusiasm. Apart from the military, it was practiced also by the aristocracy and rich landowners. A good example was Prince Friedrich Karl of Prussia, member of the German equestrian team for the 1912 Summer Olympics in Stockholm, where the first Olympic show jumping event was held (Łysakowska, 2000). In the history of the region, Prince Friedrich came to be remembered as the first equestrian Olympian, one whose successes in the arena led to an increased popularity of horse riding and an official decision to begin construction of a hippodrome in Insterburg in 1919 (Knoblauch, 1939). Before long the new arena and the thriving horse breeding industry of East Prussia elevated the region to the forefront of European equestrianism (Lehndorff, 1980, p. 113).

High command of the Prussian army attached great importance to the quality of the military horse. Rigorous specifications for equine breeders to comply with were formulated and a variety of tools to test and further improve the condition of the supplied stock were devised. One of them was the Military Horse Championship initiated in France in 1900, a bravery test to fathom the usability of the horse for patrolling missions and other cavalry operations (Urban, 2003, p. 165). It triggered the appearance of yet another equestrian sport, today known as eventing, whose complexity is perhaps best expressed by its French name: 'Concours Complet d'Equitation', i.e. the comprehensive equestrian contest. From the start, Trakenher horses proved successful in this extremely difficult discipline, as the first official contest held in Lucerne in 1927 was won by a Prussian aristocrat, Prince Friedrich Sigismund (Łysakowska, 2000, p. 28).

\section{Goal and methodology}

This paper intends to outline the background and the context of the development of equestrian sports in Varmia and Masuria and the establishment of Polish state studs and stallion stations in the region. Research data 
used in it were sourced from publications by German authors (Knoblauch, 1939; Lehndorff, 1980; Schute, 1987; Donhoff, 1988), a Belarusian author (Kamzolov, 2002), and Polish authors (Josse, 1959; Pacyński, 1960; Urban, 2003; and Wójcik, 2010), their analysis reveling various stages in the growth of horse reproduction sites and their impact on the popularity of recreational horse riding and the quality of sports results achieved by members of studbased riding sections in the region. A substantial amount of essential information on equestrian competition was also obtained from official records of Liski and Rzeczna Studs and local press, as well as master's theses and doctoral dissertations.

\section{Equine breeding traditions in Varmia and Masuria}

Horse breeding had flourished in the region when it was still East Prussia, with Trakehnen Stud being a jewel in the crown of the local equine breeding industry (Kamzolov, 2002). In time, the establishment was expanded to include an indoor manège, a race track, and a jockey school (Kamzolov, 2002). Among another six breeding sites administered by the government in Konigsberg were two stallion stations, in Rostenburg (today's Kętrzyn) and in Braunsberg (Braniewo), both initially overseen by a senior stable master, later on by a renowned hippologist, Gustaw Rau (Wójcik, 2010). Every year they supplied large numbers of fine horses to their principal customer, the Prussian army.

But horses were bred successfully also on country estates of the local aristocracy and gentry. The elite of the Prussian society of the time, who customarily considered the horse an indispensable element of everyday life, had set up a network of twenty-seven private stud farms such as, for example, Geissels (Gisiel), Prokelwitz (Prakwice), and Gr. Bestendorf (Dobrocin), all located near Mohryngen (Morag), the birthplace of writer Walther Harich (18881931), author of 'Der Aufstieg' saga, or the already mentioned Rastenburg Stud, which prided itself on producing three superb mounts: Fasan, Nurmia, and Kurfust. Together with their riders, these splendid animals won medals during the 1936 Olympic Games in Berlin, bringing well deserved glory to the region. Not far from Braunsberg, home to Richard Schirmann, keen advocate of tourism for schoolchildren, thrived a stallion station and Korbsdorf Stud. In another corner of East Prussia, Preußsich Holland (Pasłęk), horses were bred in Jankendorf (Jankowo), Slobitten (Słobity), Schodien (Gładysze), and Behlendorf (Bielica) (Josse, 1959, p. 76; Wójcik, 2014, p. 334). Finally, one must not forget a land estate near Bartenstein (Bartoszyce) owned by Mr. von Kuenheim (Grodzicki, Pacyński, 1966, p. 7), and a stud farm in Loyden (Lojdy) belonging to a German landowner by the name of Negeborn.

Summing up, after World War 1, East Prussia exported horses to 14 countries in Europe, North America, and Asia (Kamzolov, 2002, p. 110), and the Prussian town of Insterburg repeatedly hosted German national equestrian teams training for three consecutive Olympiads: in Amsterdam (1928), Berlin (1936), and Helsinki (1940) (Kamzolov, 2002). Without the necessary facilities and years of experience neither of these would have been possible.

\section{State studs and stallion farms in Olsztynskie Province}

1947 was a breakthrough year for Polish horse breeders and equestrians in Varmia and Masuria. This is when, on the initiative of dr. Witold Pruski, head of the Horse Breeding Department of the Polish Ministry of Agriculture and Agricultural Reform, and in collaboration with Adam Sosnowski of the Sopot Branch of the Polish State Horse Breeding Farms, the first stage of restoration of horse breeding in the region began, a process which soon gave impetus to the development of equestrian sports in Olsztyńskie Province. In April 1947, former Prussian Rastengurg estate was reopened as Polish Kętrzyn Stallion Station (Wójcik, Skrzypczak, 2014, p. 241). A month later, three 
other sites began to operate, Garbno, Liski, and Rzeczna Studs respectively (Josse, 1959, p. 74). In the beginning, none of these ventures exhibited a strictly horse breeding or equestrian orientation per se. Their initial role consisted mainly in rounding up horses of all breeds scattered across the country and receiving equines that had either been imported or repossessed.

For a number of years Liski Stud was a leading enterprise in the region. Its staff had been obligated to learn to ride, and their horsemanship skills were demonstrated to the general public at a variety of events held either on site or in the vicinity. Since other stud farms did the same, together they became a natural basis for the local equestrian movement, which, in the course of time, transformed into a fully-fledged sport (Wójcik, 2010).

Braniewo (formerly Braunsberg) had had years of experience and offered technical facilities that survived the war in a relatively unscathed condition. This is where, in 1951, an official equestrian contest was organized as part of a Polish-Soviet comradeship festival. Solely amateur and primarily propagandist in character, the competition attracted teams of riders from many newly-established state studs. Events like this integrated local horse breeders and laid the foundation for the emergence of equestrian sports structures in the future.

Meanwhile, with considerable support from Mr. Witold Podczasi, former Hohenzollerns' manor by the name of Kadinen was transformed into Kadyny State Stud (Francuz, 1966, p. 3). The underlying idea here, too, was that Trakenher horse should be brought back to places where the breed had originated in order to assure optimal conditions for its further growth, and, as was already mentioned, Varmia and Masuria boasted centuries-long tradition in this respect.

Another important development that came about in 1951 was the foundation of the Central Stud Farms Management Agency, headed by Stanisław Arkuszewski, former Polish cavalry officer and former director of the Polish State Horse Breeding Farms. Mr. Arkuszewski then helped to constitute the Equestrian Section of the Central Physical Education Board, and chaired it for several years, so a prospect of reactivation of equestrian sports gradually opened up. Indeed, a host of propagandist horse-riding competitions were soon held all across the country. At the time there were 10 stud farms in Varmia and Masuria, and another 44 studs and 14 stallion stations in other parts of Poland (Grabowski, 1973), with a stock of 2,768 mares and 1,885 stallions in total (Grabowski, 1982 , p. 84). Generally speaking, the first half of the 1950 s was characterized by an intense growth in popularity of equestrian recreation, which shortly led to the emergence of equestrian sports. Olsztyńskie Provice, with a welldeveloped network of horse-breeding establishments and good quality of breeding stock, lent itself remarkably well to equestrianism. It is no coincidence then that riders from Varmian and Masurian stud farms, i.e. Henryk Choczilewski (Liski Stud), Edward Perzyna (Braniewo Stud), and Stanisław Przybylak (Plękity Stud), were selected to join the Polish national equestrian team (APO, WKKF, No. 444/22, p. 57). The early 1950s was also a period when equestrian sports picked up the much needed momentum. Masurian horses did very well both in driving and under saddle, even though it was not until the beginning of the 1970s that the Polish government finally sanctioned saddle horse breeding and introduced a clear breeding policy to go with it. That certainly did not stop other nations, such as Austrians, Belgians, Swedes, Italians, and the Dutch, going from strength to strength astride their VarmianMasurian mounts in equestrian arenas all over the globe (Wójcik, 2010).

\section{Role of horse breeding industry in the development of equestrians sports}

The equestrian movement in Varmia and Masuria was initiated by chief state stud administrators, who were, as a rule, keen enthusiasts of horsemanship. In the pioneering years following the end of WW2, it was through their 
perseverance that the finest stock would be presented to audiences gathered for in-house stud fests and picnics, and the best horsemen among the grooms put on shows of riding prowess. In this way approval of local government officials was won, allowing inter-stud competition to begin. Since no formal equestrian sport structure existed at the time, the competition, chiefly in jumping, had to be organized by state stud managers themselves. In 1952 , two local riding teams and their horses, one form State Stallion Station in Braniewo, the other from State Stallion Station in Kętrzyn, made their debut at a national-level equestrian contest in Wrocław (Habinowska, 1986, p. 71). Years of hard selective work paid off in 1955, when Henryk Choczilewski of Liski Stud won the first bronze medal in jumping at the Polish National Championships in the post-war history of the region. This extraordinary success would not have been possible without his splendid mount, Bosman, well prepared for the occasion by a local zootechnician and horse trainer (ASOSG, p. 121). National championships that came along in the following years brought new triumphs. Ultimately, in 1956 the original between-stud-farm-rivalry transformed into regular sports competition, the first local contest of the kind to be held on April 29, 1956 (Wójcik, 2010, p. 231).

In-house riders competed on the best horses bred on their own stud farms. These were, for example, Bosman, Boksana, Bolgamie, and Chloe at Liski Stud; Czarnków, Czarownik, War, and Kulnar at Rzeczna Stud; Wareg, Wolbórz, and Pregor at Kętrzyn Stallion Station; and Narwik, Balador, and Klejnot at Braniewo Stallion Station. The situation was similar in less renowned, rural sites such as Plękity, Kadyny, Warniki Łozaj, Popielno, and Kroplewo, although their horses, originating from breeding stock of lesser quality, were bound to achieve successes of much less spectacular a caliber. Nonetheless, pairs from all these stud farms participated with great enthusiasm in regional and zonal competitions. They were soon joined by equally enthusiastic contestants from breeding establishments located in the neighboring provinces, participation in these events having become an excellent form of advertisement and evaluation of the quality of breeding.

Due to systematic advances in horsemanship and passionate involvement of horse riding staff of Liski Stud, national-level competitions came to Varmia (i.e. to Bartoszyce) in 1960 (ASKL, p. 2; Już pierwsze zgłoszenia..., 1960, p. 2). The inaugurating contest brought together riders and 94 horses from 13 clubs from all across the country, including members of the Polish national equestrian team (Marian Babirecki, Andrzej Kobyliński and Andrzej Orłoś), training for the Olympic Games in Rome at the time. A large number of spectators arrived in the town hosting the event, many of them Polish buyers intending to purchase the finest horses. It should be noted that, at the very same time, Venice, Italy, was the venue of the European Junior Championships in jumping, where Poland was represented by two brothers, Antoni and Tomasz Pacyński, both Liski Stud in-house riders. Their performance in this prestigious competition brought much splendor to the region and the country because Antoni, astride a local horse named Bolgami, won a silver medal in individual contest, and his excellent disposition contributed significantly to the Polish team winning a silver medal (Chachuła, Bucholc-Ferenstein, 1981, p. 167). For the record, these were not the only Polish triumphs in European Championships.

Two years after the Venice success, in view of the ever improving results in horse breeding and sports competition in the region, Polish Equestrian Association decided that the next Polish Championships should be held in Olsztyn. Out of 77 participants, as many as six were local equestrians. They performed very well, and the good impression they had made was seen as a promise of major successes in the future. In 1963 Varmia and Masuria finally became the venue of an international equestrian contest. While it was in progress, the executive board of Polish Equestrian Association arrived in Olsztyn for a two-day session (June 16-17, 1963). This is how they commented on their choice: Varmia and Masuria is a region that excels in horse breeding, not only in Europe, but 
also in the world. That is exactly why we decided to locate the international equestrian contest here. Western Europe prides itself on Aachen, we intend to be the best in Eastern Europe (Głos Olsztyński, 1963, p. 6).

For over ten years to come annual competitions under the auspices of the International Federation for Equestrian Sports helped promote the horse breeding industry and the equestrian movement which local breeders so ardently supported. Not surprisingly, further triumphs soon followed. In 1964, representing Rzeczna Stud, Michał Siemion on Condylus won a bronze medal at the Polish Championships in dressage. It was not long before two other riders from the same facility, Bernard Kuleta and Henryk Hucz, began to score successes, too. Rzeczna Stud produced excellent stock, too: a mare named Drobnica, ridden by Jan Kowalczyk, member of the Polish national equestrian team, was well known at arenas around the world. Other horse athletes that made local equestrian history were Bojgard, Deptak, and Wodnik.

In 1966 Varmia and Masuria's horse breeding industry attracted attention of the central government in Warsaw. Between July 4 and July 8 that year all state studs and stallion stations in the region were visited by members of the Equine Breeding Commission, an advisory body to the Research Council for the Animal Husbandry Union. The visit ended in an official session, chaired by dr. Jan Grabowski, during which the researchers adopted a four-item resolution that began with the following sentence: 'The quality of horse breeding in Masurian studs is high and the breeding policy purposeful' (Koń Polski, 1966, p. 42). Local breeders and equestrians received this complimentary opinion with great satisfaction. That it was well deserved was confirmed two years later when a Liski Stud rider, Marcin Pacyński on Legat, won a bronze medal in team eventing in France during the Junior European Equestrian Championships (Gaj, 1987, p. 262). By that time Masurian mounts were already in high demand, the finest of them often used by breeders of the Wielkopolski horse. Many that proved themselves in competition got sold to Canada, Germany, and the USA. Polish riders would often be competing against some of them in European and Olympic arenas around the world (Wójcik, 2010, p. 80).

In 1970, Olsztyn hosted the Polish Equestrian Championships for the second time. Although six local pairs successfully represented the region, only one of them, Antoni Pacyński (Liski Stud) on Leonidas, winners of the silver medal in dressage, was numbered among top pairs of the event. Antoni's brother, Tomasz Pacyński (Kadyny Stud) on Sztorm came in third (Wójcik, 2010, p. 291). Popularity of equestrianism in Varmia and Masuria in the 1970s soared. Horsemen from local studs enjoyed recognition in national and European arenas. A good example was Tadeusz Czermiński of Rzeczna Stud, who in 1974 won a bronze medal in four-in-hand driving in team competition (Czermiński, 1998, p. 107), and repeated his success the following year, at the 1975 European Championships in Sopot (Koń Polski, 1975, p. 18). Incidentally, Prince Philip, Duke of Edinburgh, who was a contestant in the Sopot driving contest, must have found the quality of the local horse population of interest because immediately after the championships were over he paid a visit to Rzeczna Stud (Wójcik, 2012, p. 195). Before the 1975 season came to an end, equestrians from Olsztyn had won as many as five medals at Polish championships, which was, and still is, by far the best result achieved by a single horse-riding club in the post-war history of Polish equestrianism.

However, an achievement that calls for particular acknowledgement is the fact that a tiny village of Liski produced riders who managed to qualify for Olympic-level competition. Antoni Pacyński on Cirrus ${ }^{1}$ competed in the 1968 Summer Olympics in Mexico. Of a group of 20 riders training for the next Olympiad in Munich (1972), as

${ }^{1}$ A. Pacyński came in $38^{\text {th }}$ in individual competition, and $10^{\text {th }}$, together with Jan Kowalczyk, Marian Kozicki, and Piotr Wawryniuk, in team competition (cf. Urban, 2013, p. 367). 
many as three represented small local riding clubs: Stefan Grodzicki (Liski Stud), Henryk Hucz (Rzeczna Stud), and Tomasz Pacyński (Kadyny Stud) (Wójcik, 2010, p. 330). Ultimately, only Stefan Grodzicki and his mare, Biszka, made to the national Olympic team. ${ }^{2}$

Successes of these and of many other equestrians from Varmia and Masuria (for example Polish championships contestants) are still vividly remembered and appreciated. Some equestrian careers of the time have for years been held up to new generations of horsemen and horsewomen as examples to follow (see competition results in Table 1).

Table 1. Results of competitors from Warmińsko-Mazurskie breeding centers in the Polish Senior Equestrian Championships (1955-1975)

\begin{tabular}{|c|c|c|c|}
\hline Competition & Dressage Competition & Jumping Competition & The Three-Day Event \\
\hline 1 & 2 & 3 & 4 \\
\hline 1955 & Sopot & Sopot & They were not played \\
\hline Champion & $\begin{array}{l}\text { Marek Roszczynialski } \\
\text { (Ariol) - Stubno }\end{array}$ & $\begin{array}{l}\text { Maciej Świdziński } \\
\text { (Argun) - Moszna }\end{array}$ & - \\
\hline I vice champion & $\begin{array}{l}\text { Tomasz Tokarczyk } \\
\text { (Bej) - Racot }\end{array}$ & $\begin{array}{l}\text { Władysław Byszewski } \\
\text { (Besson) - Moszna }\end{array}$ & - \\
\hline Il vice champion & $\begin{array}{c}\text { Bernard Gellert } \\
\text { (Bałagan) - Racot }\end{array}$ & $\begin{array}{c}\text { Henryk Choczilewski } \\
\text { (Bosman) - Liski }\end{array}$ & - \\
\hline 1957 & Poznań & Poznań & Łobez \\
\hline Champion & $\begin{array}{l}\text { Wojciech Zbanyszek } \\
\text { (Dystanz) - Łobez }\end{array}$ & $\begin{array}{l}\text { Marian Kowalczyk } \\
\text { (Pregor) - Poznań }\end{array}$ & $\begin{array}{l}\text { Marek Roszczynialski } \\
\text { (Ariol) - Łobez }\end{array}$ \\
\hline I vice champion & $\begin{array}{l}\text { Romana Orłowska } \\
\text { (Bagalpur) - Poznań }\end{array}$ & $\begin{array}{l}\text { Antoni Pacyński } \\
\text { (Bosman) - Liski }\end{array}$ & $\begin{array}{c}\text { Jan Kowalski } \\
\text { (Czar Walca) - Sieraków }\end{array}$ \\
\hline Il vice champion & $\begin{array}{c}\text { Feliks Drozd } \\
\text { (Bałagan) - Racot }\end{array}$ & $\begin{array}{c}\text { Jan Kubiak } \\
\text { (Erotyk) - Kwidzyn }\end{array}$ & $\begin{array}{l}\text { Only two riders he finished the } \\
\text { competition }\end{array}$ \\
\hline 1960 & Wroclaw & Wroclaw & They were not played \\
\hline Champion & $\begin{array}{l}\text { Marian Babirecki } \\
\text { (Volt) - Kwidzyn }\end{array}$ & $\begin{array}{l}\text { Stanisław Kubiak } \\
\text { (Wareg) - Kwidzyn }\end{array}$ & - \\
\hline I vice champion & $\begin{array}{l}\text { Marian Kowalczyk } \\
\text { (Mitrydat) - Poznań }\end{array}$ & $\begin{array}{l}\text { Antoni Pacyński } \\
\text { (Bolgami) - Liski }\end{array}$ & - \\
\hline II vice champion & $\begin{array}{c}\text { Andrzej Orłoś } \\
\text { (Botwid) - Kwidzyn }\end{array}$ & $\begin{array}{l}\text { Marian Kowalczyk } \\
\text { (Pregor) - Poznań }\end{array}$ & - \\
\hline 1964 & Gniezno & Gniezno & Łobez \\
\hline Champion & $\begin{array}{l}\text { Marian Babirecki } \\
\text { (Volt) - Moszna }\end{array}$ & $\begin{array}{c}\text { Andrzej Orłoś } \\
\text { (Bao Day) - Kwidzyn }\end{array}$ & $\begin{array}{l}\text { Marian Babirecki } \\
\text { (Volt) - Moszna }\end{array}$ \\
\hline I vice champion & $\begin{array}{c}\text { Janusz Nowak } \\
\text { (Britus) - Poznań }\end{array}$ & $\begin{array}{c}\text { Franciszek Ciebielski } \\
\text { (Hrabia) - "Legia" Warszawa }\end{array}$ & $\begin{array}{c}\text { Andrzej Orłoś } \\
\text { (Dysproz) - Kwidzyn }\end{array}$ \\
\hline II vice champion & $\begin{array}{c}\text { Michał Siemion } \\
\text { (Condylus) - Rzeczna }\end{array}$ & $\begin{array}{l}\text { Janusz Nowak } \\
\text { (Britus) - Poznań }\end{array}$ & $\begin{array}{l}\text { Only two riders he finished the } \\
\text { competition }\end{array}$ \\
\hline 1967 & Poznań & Radom & Poznań \\
\hline Champion & $\begin{array}{c}\text { Marian Kowalczyk } \\
\text { (Sekt) - Poznań }\end{array}$ & $\begin{array}{c}\text { Jan Kowalczyk } \\
\text { (Drobnica) - "Legia" Warszawa }\end{array}$ & $\begin{array}{c}\text { Bernard Kuleta } \\
\text { (Wodnik) - Rzeczna }\end{array}$ \\
\hline I vice champion & $\begin{array}{c}\text { Marian Babirecki } \\
\text { (Grigorij) - "Legia” Warszawa }\end{array}$ & $\begin{array}{c}\text { Stefan Grodzicki } \\
\text { (Biszka) - Liski }\end{array}$ & $\begin{array}{c}\text { Zbigniew Madejczyk } \\
\text { (Demon Schagya) - Bogusławice }\end{array}$ \\
\hline II vice champion & $\begin{array}{c}\text { Janusz Nowak } \\
\text { (Istambuł) - Poznań }\end{array}$ & $\begin{array}{c}\text { Antoni Pacyński } \\
\text { (Remus) - "Służewiec" Warszawa }\end{array}$ & $\begin{array}{c}\text { Stefan Kumorek } \\
\text { - (Nalot) "Podhalanin" Wadowice }\end{array}$ \\
\hline
\end{tabular}

${ }^{2}$ S. Grodzicki came in $16^{\text {th }}-20^{\text {th }}$ individually, and $12^{\text {th }}$ in team competition (cf. Urban, 2013, p. 367). 


\begin{tabular}{|c|c|c|c|}
\hline 1 & 2 & 3 & 4 \\
\hline 1968 & Poznań & Nie rozgrywano & Poznań \\
\hline Champion & $\begin{array}{l}\text { Marian Kowalczyk } \\
\text { (Sekt) - Poznań }\end{array}$ & - & $\begin{array}{c}\text { Zbigniew Ciesielski } \\
\text { (Skok) - "Legia" Warszawa }\end{array}$ \\
\hline I vice champion & $\begin{array}{l}\text { Wojciech Mickunas } \\
\text { (Dżemila) - Poznań }\end{array}$ & - & $\begin{array}{l}\text { Wojciech Mickunas } \\
\text { (Dżemila) - Poznań }\end{array}$ \\
\hline II vice champion & $\begin{array}{c}\text { Marek Skrzypczyk } \\
\text { (Herszt) - Bogusławice }\end{array}$ & - & $\begin{array}{c}\text { Bernard Kuleta } \\
\text { (Wodnik) - Rzeczna }\end{array}$ \\
\hline 1969 & Kwidzyn & Kwidzyn & Racot \\
\hline Champion & $\begin{array}{l}\text { Marian Kowalczyk } \\
\text { (Sekt) - Poznań }\end{array}$ & $\begin{array}{c}\text { Jan Kowalczyk } \\
\text { (Blekot) - "Legia" Warszawa }\end{array}$ & $\begin{array}{l}\text { Wojciech Mickunas } \\
\text { (Dżemila) - Poznań }\end{array}$ \\
\hline I vice champion & $\begin{array}{c}\text { Gerard Fröllich } \\
\text { (Gładzysz) - Kwidzyn }\end{array}$ & $\begin{array}{c}\text { Stefan Grodzicki } \\
\text { (Biszka) - Liski }\end{array}$ & $\begin{array}{c}\text { Mirosław Szefer } \\
\text { (Nalot) - "Podhalanin" Wadowice }\end{array}$ \\
\hline II vice champion & $\begin{array}{l}\text { Wojciech Mickunas } \\
\text { (Dżemila) - Poznań }\end{array}$ & $\begin{array}{l}\text { Stefan Stanisławiak } \\
\text { (Scheda) - Racot }\end{array}$ & $\begin{array}{c}\text { Stefan Kumorek } \\
\text { (Bałagan) - Klikowa }\end{array}$ \\
\hline 1970 & Olsztyn & Olsztyn & Książ \\
\hline Champion & $\begin{array}{l}\text { Marian Kowalczyk } \\
\text { (Sekt) - Poznań }\end{array}$ & $\begin{array}{c}\text { Jan Kowalczyk } \\
\text { (Blekot) - "Legia" Warszawa }\end{array}$ & $\begin{array}{l}\text { Zbigniew Madejczyk } \\
\text { (Bursz) - Bogusławice }\end{array}$ \\
\hline I vice champion & $\begin{array}{l}\text { Antoni Pacyński } \\
\text { (Leonidas) - Liski }\end{array}$ & $\begin{array}{l}\text { Piotr Wawryniuk } \\
\text { (Poprad) - Poznań }\end{array}$ & $\begin{array}{c}\text { Gerard Fröllich } \\
\text { (Gładzysz) - Kwidzyn }\end{array}$ \\
\hline II vice champion & $\begin{array}{l}\text { Tomasz Pacyński } \\
\text { (Sztorm) - Kadyny }\end{array}$ & $\begin{array}{c}\text { Marian Kozicki } \\
\text { (Bronz) - "Legia" Warszawa }\end{array}$ & $\begin{array}{l}\text { Wojciech Mickunas } \\
\text { (Giecz) - Racot }\end{array}$ \\
\hline 1971 & Warszawa & Warszawa & Starogard Gdański \\
\hline Champion & $\begin{array}{l}\text { Antoni Pacyński } \\
\text { (Leonidas) - Liski }\end{array}$ & $\begin{array}{l}\text { Piotr Wawryniuk } \\
\text { (Poprad) - Poznań }\end{array}$ & $\begin{array}{c}\text { Zbigniew Ciesielski } \\
\text { (Damaszek) - "Legia" Warszawa }\end{array}$ \\
\hline I vice champion & $\begin{array}{l}\text { Marian Kowalczyk } \\
\text { (Sekt) - Poznań }\end{array}$ & $\begin{array}{c}\text { Marian Kozicki } \\
\text { (Bronz) - "Legia" Warszawa }\end{array}$ & $\begin{array}{l}\text { Jacek Wierzchowiecki } \\
\text { (Mistral) - Poznań }\end{array}$ \\
\hline II vice champion & $\begin{array}{l}\text { Stefan Grodzicki } \\
\text { (Tarnów) - Liski }\end{array}$ & $\begin{array}{c}\text { Stefan Grodzicki } \\
\text { (Biszka) - Liski }\end{array}$ & $\begin{array}{c}\text { Wojciech Mickunas } \\
\text { (Giecz) - Racot }\end{array}$ \\
\hline 1972 & Warszawa & Warszawa & Biały Bór \\
\hline Champion & $\begin{array}{l}\text { Antoni Pacyński } \\
\text { (Porfir) - Liski }\end{array}$ & $\begin{array}{c}\text { Marian Kozicki } \\
\text { (Bronz) - "Legia" Warszawa }\end{array}$ & $\begin{array}{l}\text { Wojciech Mickunas } \\
\text { (Armator) - Racot }\end{array}$ \\
\hline I vice champion & $\begin{array}{l}\text { Stefan Grodzicki } \\
\text { (Tarnów) - Liski }\end{array}$ & $\begin{array}{c}\text { Jan Kowalczyk } \\
\text { (Blekot) - "Legia" Warszawa }\end{array}$ & $\begin{array}{c}\text { Jan Skoczylas } \\
\text { (Cyrjak) - "Podhalanin" Wadowice }\end{array}$ \\
\hline II vice champion & $\begin{array}{l}\text { Krzysztof Tomaszewski } \\
\text { (Haust) - Łąck }\end{array}$ & $\begin{array}{c}\text { Stefan Grodzicki } \\
\text { (Biszka) - Liski }\end{array}$ & $\begin{array}{c}\text { Jan Kłym } \\
\text { (Plutokrata) - "Legia" St. Miłosna }\end{array}$ \\
\hline 1973 & Warszawa & Warszawa & Poznań \\
\hline Champion & $\begin{array}{c}\text { Jerzy Pawłowski } \\
\text { (Diogenes) - Kwidzyn }\end{array}$ & $\begin{array}{c}\text { Jan Kowalczyk } \\
\text { (Blekot) - "Legia" Warszawa }\end{array}$ & $\begin{array}{l}\text { Jacek Wierzchowiecki } \\
\text { (Gniew) - Poznań }\end{array}$ \\
\hline I vice champion & $\begin{array}{l}\text { Stefan Grodzicki } \\
\text { (Tarnów) - Liski }\end{array}$ & $\begin{array}{c}\text { Stefan Grodzicki } \\
\text { (Biszka) - Liski }\end{array}$ & $\begin{array}{c}\text { Józef Zagor } \\
\text { (Kosa) - Rzeczna }\end{array}$ \\
\hline II vice champion & $\begin{array}{l}\text { Antoni Pacyński } \\
\text { (Porfir) - Liski }\end{array}$ & $\begin{array}{c}\text { Henryk Hucz } \\
\text { (Bertyn) - Rzeczna }\end{array}$ & $\begin{array}{c}\text { Jan Kłym } \\
\text { (Plutokrata) - "Legia" St. Miłosna }\end{array}$ \\
\hline 1974 & Kwidzyn & Warszawa & Kwidzyn \\
\hline Champion & $\begin{array}{l}\text { Antoni Pacyński } \\
\text { (Porfir) - Liski }\end{array}$ & $\begin{array}{c}\text { Jan Kowalczyk } \\
\text { (Blekot) - "Legia" Warszawa }\end{array}$ & $\begin{array}{l}\text { Marek Małecki } \\
\text { (Sirca) - Moszna }\end{array}$ \\
\hline I vice champion & $\begin{array}{l}\text { Stefan Grodzicki } \\
\text { (Tarnów) - Liski }\end{array}$ & $\begin{array}{c}\text { Rudolf Mrugała } \\
\text { (Farsa) - Moszna }\end{array}$ & $\begin{array}{c}\text { Krzysztof Aftyka } \\
\text { (Odynit) - "Legia" St. Miłosna }\end{array}$ \\
\hline II vice champion & $\begin{array}{l}\text { Krzysztof Tomaszewski } \\
\text { (Haust) - Łąck }\end{array}$ & $\begin{array}{c}\text { Wiesław Dziadczyk } \\
\text { (Via Vitae) - Kozienice }\end{array}$ & $\begin{array}{c}\text { Józef Kutysz } \\
\text { (Orlik) - "Legia" St. Miłosna }\end{array}$ \\
\hline 1975 & Biały Bór & Sopot & Biały Bór \\
\hline Champion & $\begin{array}{l}\text { Krzysztof Tomaszewski } \\
\text { (Haust) - Łack }\end{array}$ & $\begin{array}{c}\text { Jan Kowalczyk } \\
\text { (Darlet) - "Legia" Warszawa }\end{array}$ & $\begin{array}{c}\text { Piotr Skwira } \\
\text { (Borta) - Nowielice }\end{array}$ \\
\hline
\end{tabular}




\begin{tabular}{cccc}
\hline 1 & 2 & 3 & 4 \\
\hline I vice champion & $\begin{array}{c}\text { Stefan Grodzicki } \\
\text { (Kobryń) - Liski }\end{array}$ & $\begin{array}{c}\text { Antoni Pacyński } \\
\text { (Postawa) - Liski }\end{array}$ & $\begin{array}{c}\text { Mirosław Ślusarczyk (Dariusz) - "Legia" } \\
\text { St. Miłosna }\end{array}$ \\
\hline II vice champion & $\begin{array}{c}\text { Antoni Pacyński } \\
\text { (Porfir) - Liski }\end{array}$ & $\begin{array}{c}\text { Henryk Hucz } \\
\text { (Bertyn) - Rzeczna }\end{array}$ & $\begin{array}{c}\text { Krzysztof Aftyka } \\
\text { (Czad) - "Legia" St. Miłosna }\end{array}$ \\
\hline
\end{tabular}

Source: own study based on Wójcik (2010).

\section{Recapitulation and conclusions}

Based on the study of the process of establishment and operation of equine breeding sites in Varmia and Masuria the following conclusions can be formulated:

1. Long tradition of horse breeding in former East Prussia exerted dominant influence on horse breeding efforts continued in Varmia and Masuria after the region had become part of Poland.

2. First Polish stud farms and stallion stations in the region were started in 1947 at four locations, Liski, Rzeczna, Garbno, and Ketrzyn, using the remaining Prussian infrastructure and Trakenher and East Prussian stock that survived the war.

3. Equestrian sports began to emerge soon after horse breeding facilities resumed operation, and were a direct reflection of the improving quality of the breeding stock. Outdoor picnics and fests organized by state stud managements initially played the role of horse bravery tests. To see how stock breeding and horse training endeavors of individual establishments compared, inter-stud horse riding contests were introduced. In time, these led to the creation of an official system of regional equestrian competition, which in turn allowed in-house stud riders to compete at higher levels (zonal, national, and international).

4. Equestrianism helped promote the horse breeding industry, and the results achieved in equestrian competition were strongly correlated with the quality of the stock.

5. Between 1947 and 1975, local equestrians won:

- 24 medals at Polish championships,

- 5 medals at European championships,

- 1 medal at world championships.

6. National competition, but most importantly, participation in European championships, world championships, and Olympic games, confirmed high quality of horse breeding in the region.

7. Over the years, in-house state stud riders and their horses competed at a number of Polish and European championships and, on one occasion, world championships (Tadeusz Czermiński's four-in-hand, Switzerland, 1974). The ones that contributed the most to the promotion of regional horse breeding and horse riding endeavors were Antoni Pacyński on Cirrus and Stefan Grodzicki on Biszka, who took part in Olympic-level competition (Mexico, 1968, and Munich, 1972).

\section{References}

ASKL. Archiwum Zakładowe Stadniny Koni Liski. Kronika sportowa Stefana Grodzickiego 1960-1976.

ASOSG. Archiwum Zakładowe Stada Ogierów Starogard Gdański w Rzecznej. Sport - pisma różne 1955-1980. No. 12/18.

Archiwum Państwowe w Olsztynie, WKKF, sygn. 444/22.

Chachuła, J., Bucholc-Ferenstein, W. (1981). Polskie konie wierzchowe. Warszawa: Państwowe Wydawnictwo Rolnicze i Leśne. 
Czapiewska, G. (2003). Historyczne uwarunkowania rozwoju rolnictwa uspołecznionego na Pomorzu Środkowym. Słupskie prace geograficzne, 1, 51-61.

Czermiński, T. (1998). Wspomnienia. Sieraków: Wydawnictwo W. Pelczarski.

Dönhoff, M.G. (1988). Kindheit in Ostpreußen by Marion Gräfin Dönhoff. Berlin: Siedler.

Dönhoff, M.G. (1962). Namen die keiner mehr nennt. Düsseldorf, Köln, Diederichs: Verlag.

Francuz, M. (1966). Charakterystyka stadniny koni wielkopolskich typu mazurskiego w Kadynach. Olsztyn: Wydawnictwo Wyższej Szkoły Rolniczej.

Gaj, J. (1987). Wychowanie fizyczne i sport w Polsce Ludowej. Warszawa-Poznań: Wydawnictwo Naukowe.

Głos Olsztyński (1963), 139, 6.

Grabowski, J. (1973). Hodowla koni w Polsce w latach 1918-1971. In: E. Potemkowska (ed.), Karty z dziejów zootechniki polskiej. Warszawa: Państwowe Wydawnictwo Rolnicze i Leśne.

Grabowski, J. (1982). Hipologia dla wszystkich. Warszawa: Krajowa Agencja Wydawnicza.

Grodzicki, S., Pacyński, J. (1966). Stadnina Koni Liski. Warszawa: Państwowe Wydawnictwo Rolnicze i Leśne.

Habinowska, M. (1986). Ludzie i konie. Sport jeździecki na poznańskiej Woli 1951-1953. Poznań: Państwowe Wydawnictwo Rolnicze i Leśne.

Jagielski, B. (2002). Polskie konie, stadniny, stada i kluby jeździeckie. Warszawa: Wydawnictwo "Arkady" Sp. z o. o.

Jastrzębska, E. (2002). Rola Państwowego Stada Ogierów w Kętrzynie w hodowli koni zimnokrwistych. Unpublished doctoral thesis. Olsztyn.

Jossé, W. (1959). Koń Mazurski. Kraków: Wydawnictwo Instytutu Zootechniki.

Już pierwsze zgłoszenia na wielkie zawody jeździeckie (1960). Głos Olsztyński, 102 (6).

Knoblauch, A. (1939). Reiterland Ostpreußen: 100 Jahre Renn-und Turniersport; Instenburg/Trakehnen. Tilsit: Holzner-Verlag.

Kamzolov, B.W. (2001). Historia konia trakeńskiego. Mińsk: Kawalier Pabliszers 1000.

Koń Polski (1966), 3, 42.

Koń Polski (1975), 4, 18.

Łysakowska, H. (2000). Jeźdźcy olimpijscy. Warszawa: Wydawnictwo Muzeum Łowiectwa i Jeździectwa.

Pacyński, J. (1960). Koń mazurski i jego wpływ na hodowlę polską. Przegląd Hodowlany, 8-9, 108-113.

Pacyński, J. (1968). Analiza metod hodowlanych w elitarnej hodowli koni mazurskich na przykładzie S.K. Liski. Unpublished doctoral thesis. Poznań.

Pruski, W. (1960). Hodowla koni. Warszawa: Państwowe Wydawnictwo Rolnicze i Leśne.

Pruski, W., Grabowski, J., Schuch, S. (1963). Hodowla koni. Warszawa: Państwowe Wydawnictwo Rolnicze i Leśne.

Schute, E. (1987). Getrennt vom Reich. Die Instrumentalisierung des Sports in Ostpreußen zur Zeit der Weimarer Republik. Bochum.

Urban, R. (2013). Equestrian sports in Poland between 1945-1989. Gorzów Wielkopolski.

Urban, R. (2003). Rozwój sportu jeździeckiego w Polsce w latach 1918-1939. Unpublished doctoral thesis. Poznań.

Wójcik, Z. (2010). Sport jeździecki na Warmii i Mazurach w latach 1945-1975. Olsztyn: Wydawnictwo ERZET.

Wójcik, Z. (2014). Hipiczna infrastruktura byłych Prus Wschodnich. Komunikaty Mazursko-Warmińskie, 3, 32-33.

Wójcik, Z., Skrzypczak, A. (2014). Socjal and economic foundations for the growth of equestrian sport and leisure horse riding in Warmia and Mazury. Polish Journal of natural sciences, 3, 239-250.

Cite this anticle aS: Wójcik, Z., Urban, R. (2018). Development of Equestrian Sports at State Stud Farms in Varmia and Masuria between 1947 and 1975. Central European Journal of Sport Sciences and Medicine, 4 (24), 15-24. DOI: 10.18276/cej.2018.4-02. 